\title{
THE ROLE OF HUMAN CAPITAL FOR NATIONAL INNOVATION CAPABILITY IN EU COUNTRIES
}

\author{
Rasa Aleknavičiūtè ${ }^{1}$, Viktorija Skvarciany ${ }^{2}$, Simona Survilaité $^{3}$ \\ ${ }^{1}$ Mykolas Romeris University, Lithuania, raaleknavi@mruni.eu \\ ${ }^{2}$ Mykolas Romeris University, Lithuania, viktorija.skvarciany@mruni.eu \\ ${ }^{3}$ Mykolas Romeris University, Lithuania, simona.fortress@gmail.com
}

\begin{abstract}
Innovation is essential for economic growth in developed countries. One of the most important sources of innovation is human capital. In this article, state of human capital in EU countries is investigated in order to show the relationship between human capital and national innovation performance. In the first part, theoretical assumptions of human capital importance for innovation processes are analysed. Secondly, measures of human capital are analysed and a measurement model is presented. This model is applied for investigation of state of human capital in 26 EU countries during 2002-2012. Results showed that quality of human capital is the most important factor for innovation performance. Quality indicators have even higher correlation with innovation in countries with low share of innovative enterprises (enterprises with high-level of new technology acceptance and usage). The aim of research is to analyse the theoretical importance of human capital investment for national innovation capability in EU countries, and to determine human capital aspects that foster innovation performance. Therefore, objectives are as follows: to analyse theoretical assumptions of human capital importance for innovation processes and to present the current state of research; to analyse available human capital measures and create a human capital measurement model; and to analyse state of human capital in EU countries as well as its relationship with national innovation capability.
\end{abstract}

Keywords: innovation; human capital; education; human capital measurement model; European Union.

Type of the paper: Empirical paper.

JEL Classification: J24, O30.

\section{Introduction}

Innovation is essential for economic growth in developed countries. One of the most important sources of innovation is human capital. In this article, state of human capital in EU countries is investigated in order to show the relationship between human capital and national innovation performance. In the first part, theoretical assumptions of human capital importance for innovation processes are presented. Further, measures of human capital are analysed and, a model of human capital measurement is presented. The model for investigation of state of human capital in $26 \mathrm{EU}$ countries during 2002-2012 is applied.

In fact, there are various models that analyse human capital as an element of the economic growth process (Lucas 1988; Barro 2001; Romer 1990). Human capital could have a direct effect on the economy by increasing productivity of labour, as well as an indirect effect on economic growth based on increased innovation capability. One of the best-known economic growth models is the Nelson and Phelps' (1966) model where human capital and technology frontier analysis is introduced. Economic growth is based on the level of human capital as well as on the level of technology improvisation. Countries that are far from technological frontiers could sustain their growth by adapting innovations; however, the speed of adaptation depends on the level of human capital in these countries. Countries that are close to technological frontiers could grow only by introducing innovations and this process is related to the level of human capital. In this model, human capital acts indirectly by increasing the level of technology used, thereby raising productivity. This hypothesis is supplemented by numerous empirical studies (Benos et al. 2015; Coe et al. 2009; Papalia et al. 2011, etc.). What is more, this idea 
was progressed in the Barro and Sala-Martin $(1996,2004)$ model, where regional development is analysed in detail and in Schumpeterian economic growth models where more emphasis is given on entrepreneurship and creative destruction processes. More recent studies (Vandenbussche et al. 2006; Aghion, Darlauf 2009) consider that the closer the countries are to the technological frontier, the more important are the innovation processes for their economic growth and that investment in human capital is more significant for the development of domestic innovations, especially in higher education. Therefore, the aim of the research is to analyse human capital importance to national innovation capability in EU countries and to determine human capital aspects that foster innovation performance. The objectives are as follows: 1) to analyse the theoretical assumptions of human capital importance for innovation processes and present the current state of research; 2) to analyse available human capital measures and create a human capital measurement model; 3) to analyse state of human capital in EU countries as well as its relationship with national innovation capability. Research limitations correlation analysis does not allow to revel in the causal relationships of analysed concepts, it only shows the linear relationship between two variables. In order to show dependence between defined factors more advanced methods should be used.

\section{The Interface between Innovations and Human Capital}

In the twenty first century, innovation has become a crucial part of the world. This is to say, that the world is changing due to generation of new knowledge and development of new technologies. Innovation in this paper is defined as being a separate activity through which inventions are carried out in the market for commercial purposes (Snyder et al. 2016). For instance, Karoglu and Eceral (2015) claim that innovation is one of the determinants of a company's or a region's growth. Pinto et al. (2015) state that innovation could invoke the development of 'new products, new processes, new sources of supply, the exploitation of new markets and/or new organizational forms'. What is more, Lyles (2014) claims that innovation is one of the vital elements of sustainability. Scientists agree that innovations are closely related to economic growth and development. For example, Valentinavičius (2006) says that rapid economic growth is related not only to technological renewal but also to innovation implementation in economics and business. Stepanovas and Ostašenkovaite (2013) state that innovation is the most important factor of economic growth, which helps to seek high value addition and also encourages economic development. What is more, Stepanovas and Ostašenkovaite (2013) think that innovation provides an opportunity for production technology renewal and creation of new products and services. According to the scientific literature, it is necessary to focus on innovation as it is considered to be one of the most powerful tools used for the development in different fields. The European Commission conducts annual surveys on the level of innovation development in the EU. The results of the previous survey are presented in Fig. 1.

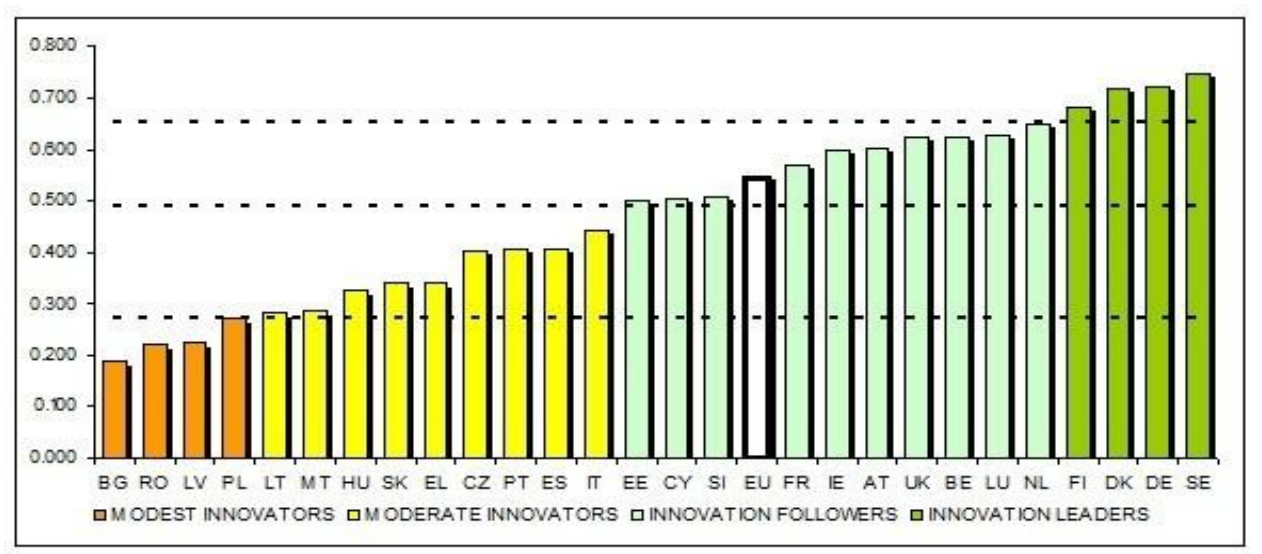

Fig. 1. EU Member States' Innovation Performance (Source: European Commission, 2015) 
According to the data in Fig. 1 it can be emphasised that although the mean level of EU countries innovation implementation is quite high and stand for innovation followers level, more than a half of the members of the EU are on the moderate level of innovation development. According to that information, it could be stated that it is necessary to pay attention to the factors that could speed up innovation implementation. In fact, a majority of innovation researches emphasise that innovations are linked to new knowledge creation (e.g. Užienè 2015; Wang 2015; Vick et al. 2015; Iturrioz et al. 2015; Lyles 2014). The knowledge creation is examined under the human capital concept in the article.

Human capital is a concept that can be investigated as a separate theory, but usually human capital is being investigated as the structural part of intellectual capital. Many authors (Bang et al. 2010; Bowman, Ambrosini 2010; Díez et al. 2010; Godoy 2008; Hughes 2010; Malgioglio et al. 2001; McLean 2006; Pitelis 2009; Wang, Swanson 2008; Zapata 2001) are accentuating the importance of human capital for the successful activities of private or public sector organisations and profit and nonprofit organisations. Although the importance of human capital is indisputable, the benefits are not clearly visible, but the importance of human capital is obvious, when it is non-existent. The basis of knowledge and information are employees, who assist in the effective and successful activity as well as in the development and the competitiveness of a respective company. Due to this basis, a company can achieve the desired objectives with the least possible cost.

Human capital can be defined as 'the knowledge, skills, competences and other attributes embodied in individuals that are relevant to economic activity' (OECD 1998, p. 9). Most commonly, human capital is described as knowledge gained through education and training. This understanding was popularised in Becker's (1975) book 'Human Capital: A Theoretical and Empirical Analysis, with Special Reference to Education', for which he was awarded a Nobel Prize in Economics (OECD, 2010). Hence, it is necessary to remember that human capital term could be extended in such areas as health, emotions and physical well-being. National intellectual capital researchers analysing human capital include such aspects as opportunities (Alexander, 2006), culture (Pasher, Shachar 2007), health (Malhotra 2003; Pasher, Shachar 2007) and labour qualification (Pasher, Shachar 2007; Lin, Edvinsson 2011). Even more implicit factors such as personal capital which relates to an individual's basic personal qualities and reflects the quality of an individual's psychological, physical, and spiritual functioning (Tomer 2003) are analysed in order to describe the level of human capital. Potelienè and Tamašauskienė (2014) summarised human capital characteristics as education, health, knowledge, competence, skills, talent, motivation, values, national culture and philosophy, labour market conditions, migration tendencies, expertise, experience, intuition, ability to understand national goals, entrepreneurship and ethics. The whole concept of human capital focuses on economic behaviour of individuals, especially the way in which their accumulation of knowledge and skills enables them to increase their productivity and earnings - and in doing so, to increase the productivity and wealth of the societies they live in (Schuller 2001).

Human capital is interpreted in various ways and different features, attributes, and several authors are accentuating peculiarities. For instance, Curado et al. (2011) accentuate a knowledge-based point of view to a company. Knowledge is the main factor of human capital. Employees with a huge knowledge can influence internal and external communication within a company.

In Table 1 the elements of human capital, which are mainly accentuated by various authors, are presented (Bontis 2010; Cabrilo 2009; Chen 2003; Green 2007; Harris 2000; Swart 2006). Stewart (1997) states that human capital is who leaves the company on weekends; human capital is who thinks. According to Stewart (1997), money talks, but does not think. Equipment and machinery work, sometimes even better than humans do, but they do not invent, do not create innovations, improvements and they do not generate ideas. The main purpose of human capital is to create innovations: to generate new ideas, to create new products, services, or goods, to improve existing products, services, or goods, to establish new business processes and so on. 
Table 1. The elements of human capital and its benefits (Source: authors' compilation)

\begin{tabular}{|l|l|}
\hline \multicolumn{1}{|c|}{ Element } & \multicolumn{1}{c|}{ Benefits } \\
\hline Knowledge & Helps to perform daily functions \\
\hline Skills & Help to perform daily functions quickly and effectively \\
\hline Know-how & Gives an opportunity to work with specific tasks or specific equipment \\
\hline Education & $\begin{array}{l}\text { Helps to understand the essence of the work, to carry out its functions through the } \\
\text { knowledge gained from the acquisition of education }\end{array}$ \\
\hline Qualification & Reveals the quality of human capital \\
\hline Motivation & Fosters to work better, faster, and with less errors \\
\hline $\begin{array}{l}\text { Willingness to } \\
\text { work }\end{array}$ & $\begin{array}{l}\text { Consequence of motivation, which helps to find the ways of solving raised issues as } \\
\text { soon as possible }\end{array}$ \\
\hline Learning & $\begin{array}{l}\text { Human capital element, which constantly increases knowledge, skills, and } \\
\text { qualification of employees }\end{array}$ \\
\hline Training & $\begin{array}{l}\text { The ability of employees not only to assimilate, but also to convey knowledge to } \\
\text { others }\end{array}$ \\
\hline Abilities & $\begin{array}{l}\text { Personal features of a human capital character /personality trait, which helps or } \\
\text { distracts to accomplish given purposes, goals, tasks, or assignments }\end{array}$ \\
\hline
\end{tabular}

According to Table 1 it can be noted that human capital has plenty of elements. Interactions between those elements constitute the essential feature of human capital - the ability to use all aforementioned elements and implement company's goals, carry out the objectives of management, stakeholders, and shareholders and to properly, efficiently and quickly perform everyday tasks. The essential function of an effective management of modern human capital - the ability to change, learn, improve, adapt to rapidly changing business conditions and the economic situation.

\section{Methodology}

Measurement of human capital is still very complicated due to the intangible nature of this resource. Limitations are even greater in the international context, where it is difficult to find measurements of human capital that are comparable and have a time perspective. There are three main approaches of human capital measurement (Le et al. 2005; Mačerinskienè, Viržintaite 2003): the cost-based approach, the income-based approach and the education-based approach. The education-based approach is most commonly used in macroeconomic studies for at least three reasons (Giménez et al. 2015): due to the proposition that formal education is the fundamental source of human capital acquisition, due to strong correlation between this and other acquisition paths and due to the existence of comparable international data. In this article, the education-based approach is used. Most popular indicators of human capital in this approach are average years of schooling, school enrolment rates, adult literacy rates and quality of schooling indicators (Le et al. 2005). All those measures have their advantages and disadvantages.

Judson (2002) notes that adult literacy rates could be a good proxy for human capital only in countries where the populace has little education as this measure captures only the elementary level of education. In recent studies it is measured as digital readiness, computer literacy and skills related to new technologies use (INSEAD eLab 2009; Welsum, Lanvin 2012; Jokūbauskienè 2013). In this research, computer and internet use skills are used as proxy for human capital.

School enrolment rates as a measure of human capital represents the flow that adds to the existing stock of education. This measure only tracks investments in human capital more than human capital stock. In this study two indicators are used to describe participation in education.

In economic growth models (Lucas 1988; Rebelo 1992; Barro 1996; Barro, Lee 2011; Benhabib, Spiegel 1994; Krueger, Lindahl 2001; Meschi, Scervini 2014; Morrisson, Murtin 2013) human capital 
is measured as educational attainment. This proxy could be based due to the differences in the educational system in countries and due to the quality of the educational system. In this research, human capital proxied by tertiary and secondary education attainment is evaluated.

According to Hanushek and Kimko (2000), quality issues have been overlooked in many studies as proxies use only education attainment indicators. In the presented study, to assess the quality of education international skills assessment tests results are chosen (PISA survey and population digital skills measures measured in Information and Communication Technologies surveys and general rate of satisfaction with education). Satisfaction of education is measured during an academically driven cross-national European Social survey. In this survey, respondents are asked to evaluate the overall state of education in a country. In this research, results of different survey rounds are used (ESS Round 1, ESS Round 2, ESS Round 3, ESS Round 4, ESS Round 5, ESS Round 6). Human capital measurement model and indicators used are summarised in Figure 2.

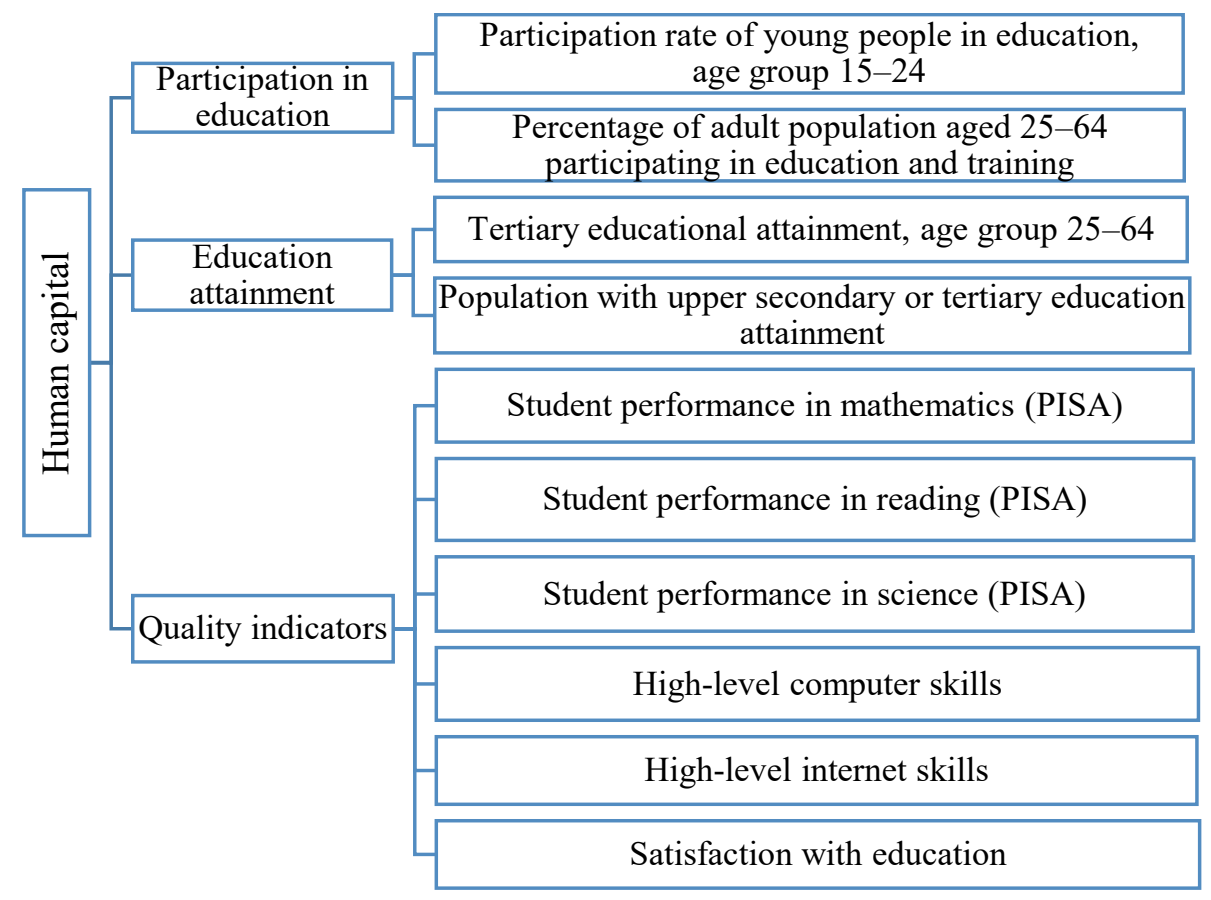

Fig. 2. Human capital measurement model (Source: authors' compilation)

Human capital indicators are divided into three groups. The first group shows participation rates in education; it represents the flow of knowledge acquisition. Second group consists of education attainment indicators and the last group captures quality indicators.

Innovation could be measured by combining several dimensions of technology-related activities (Dakhli, De Clercq 2004). Most commonly used measures are number of patents filed (Jaffe 1989), the expenditures for R\&D (Ritsila 1999), the number of innovations reported in trade journals and research periodicals (Acs et al. 1994) and data self-reported by the companies (Keeble 1997), technology-based export (Bianchi 2001). All the mentioned measures of innovations have their strengths and weaknesses. In this study, we have chosen to use self-reported number of innovations as indicators of national innovation capability. This measure evaluates innovation by its actual output. Data is collected from national community innovation surveys based on the Oslo Manual, OECD/European Commission, 2005. Measure indicates share of product and/or process innovative enterprises, regardless of organisational or marketing innovation (including enterprises with abandoned/suspended or ongoing innovation activities). Enterprises in all core NACE activities related 
to innovation activities (C, D, E, I, J, G51, K72, K74.2, K74.3) are evaluated.

In order to examine the relationship between human capital and innovation capabilities, correlation analysis is performed. This model is applied for investigation of state of human capital in $26 \mathrm{EU}$ countries (Austria, Belgium, Bulgaria, Cyprus Czech Republic, Germany, Denmark, Estonia, Greece, Spain, Finland, France, Hungary, Ireland, Italy, Lithuania, Luxembourg, Latvia, Netherlands, Poland, Portugal, Romania, Sweden, Slovenia, Slovakia, United Kingdom) during the 2002-2012 period. The data from Eurostat, European Social survey and PISA surveys results is used. Missing data is imputed by using multiple imputation predictive mean matching procedures within five iterations. For grouping the countries k-mean method of cluster analysis was used.

\section{Results}

To start with, an average share of innovative enterprises in each country is presented (see Fig. 3). Countries are grouped into two clusters according to the share of innovative enterprises (country's dependence to cluster is marked with different colours).

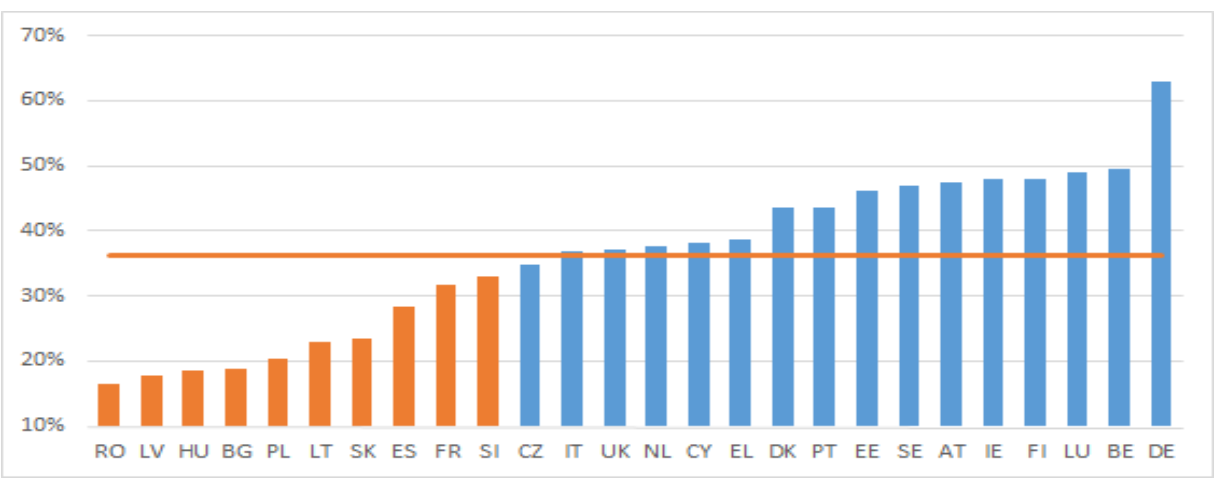

Fig. 3. Share of innovative enterprises in EU countries average of 2002-2012 (Source: Eurostat, 2015)

Share of innovative enterprises differs considerably in EU countries. The average share of innovative enterprises in EU is 36\%. The lowest share of innovative enterprises are in Romania (16\%), Latvia $(18 \%)$ and Hungary (19\%). The highest rate of innovative enterprises are in Denmark (63\%).

An analysis of the bivariate correlation coefficients provides some interesting results (Fig. 4).

Education attainment indicators show weak correlation significant at 0.05 significance level with innovation performance in a country. Tertiary education attainment is positively correlated, though share of upper secondary or tertiary education attainment is negatively correlated to innovation performance. Such results show that secondary education in EU countries is not the factor that fosters innovation. Tertiary education might be that factor, but weak correlation shows that other human capital aspects are more important than formal education attainment. This presumption is strengthened by analysing correlation of innovation performance with human capital quality indicators.

Strongest correlation is between high-level of computer skills and innovation performance $\left(0.486^{* *}\right)$, second strongest correlation is between student performance in reading (PISA) and innovation performance- $(0.472 * *)$. In addition, there is average statistically significant correlation between satisfaction of education and innovation performance $\left(0.437^{* *}\right)$. It could be noticed that all human capital indicators that have highest correlation with innovations describe the quality of human capital.

This shows the importance of human capital quality for innovation performance. In addition, lifelong learning is important for innovation. Lifelong learning and innovation performance indicators correlation is 0.400 and statistically significant. 


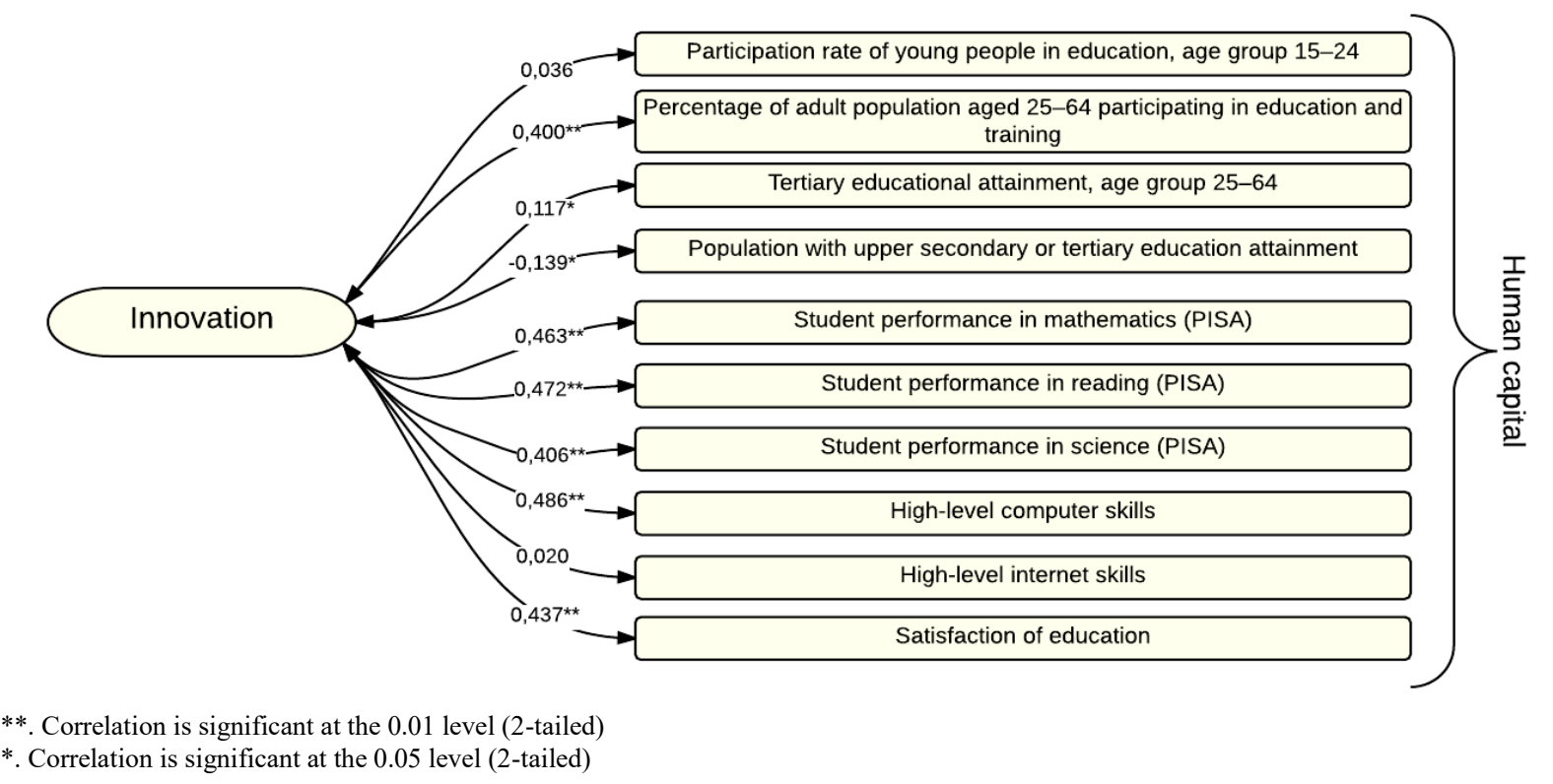

Fig. 4. Human capital indicators correlation with share of innovative enterprises in EU countries 20022012 (Source: authors' calculations)

Analysis showed that there is no statistically significant relationship between participation rate of young people in education and innovation performance and between high-level of internet skills and innovation performance. From the human capital indicator group reflecting quality, only a share of the population having high internet skills is not related to innovation performance. High-level of internet skills measures the share of individuals who have carried out five of the six internet-related activities. They are as follows: use of a search engine to find information; send an e-mail with attached files; post messages to chat rooms, newsgroups or any online discussion forum; use the internet to make telephone calls; use peer-to-peer file sharing for exchanging movies, music and so on; create a web page. Such competencies are more related to the ability to use already created technologies and most of those skills relate to communication and entertainment purposes This explains why this indicator does not correlate with innovation performance although high-level computer skills are strongly correlated to innovation performance This proxy measures the share of individuals who have carried out five of the six internet-related activities. They are as follows: copy or move a file or folder; use copy and paste tools to duplicate or move information within a document; use basis arithmetic formula (add, substract, multiply, divide) in a spreadsheet; compress files; connect and install new devices, for example, a printer or a modem; write a computer program using a specialised programming language. Those skills are mainly related to individuals' ability to use information in a digital environment, such skills are essential for innovation process.

In order to test if those indicators correlation is different in countries' groups that were identified according to the level of innovation, correlation coefficients were calculated (Table 2). 
Table 2. Human capital indicators correlation with share of innovative enterprises in EU countries clusters 2002-2012 (Source: author's calculation)

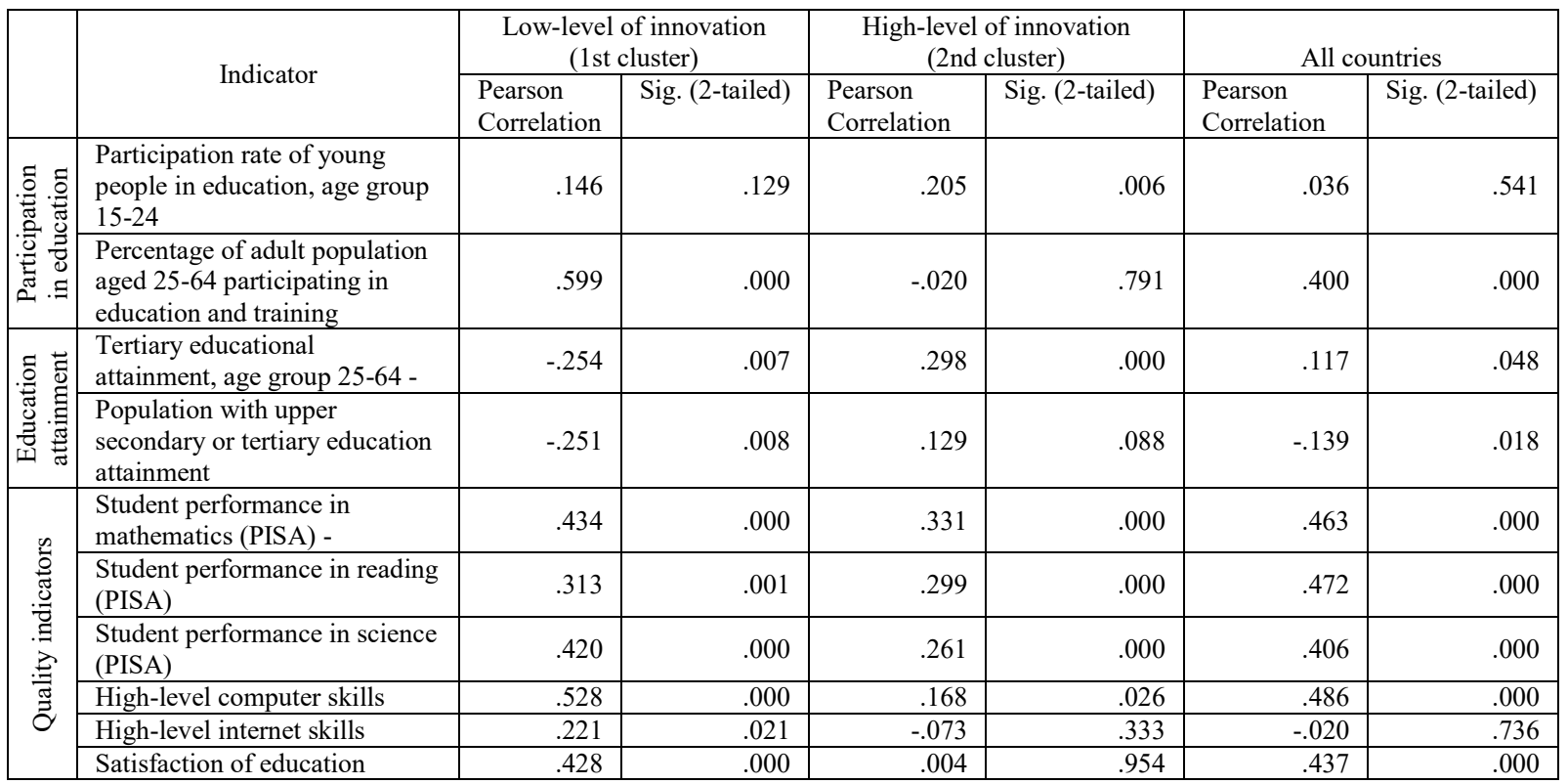

Results showed that in countries with low share innovative enterprises more aspects of human capital have significant correlation with innovation performance. In this group, internet skills show significant correlation with innovation level. Only one indicator participation of young people in education is not related to innovation performance. In countries, the group that has high share of innovative enterprises, the participation rate of young people in education is significantly related to innovations. However, in countries with high-level of innovation performance, lifelong learning is not related to innovation performance.

Education attainment indicators in countries with low-level of innovation performance is negatively correlated to innovation performance as in countries with high-level of innovation performance tertiary education attainment is positively correlated to innovation performance and upper secondary education attainment is not related to a country's innovation performance. Such differences in the relationship between education attainment and innovation performance might arise due to differences in the educational system in those countries. Countries having very high education attainment levels has very low-level of innovation.

While analysing the relationship between human capital quality indicators and innovation performance in different countries' groups it could be noticed that correlation coefficients of those indicators are stronger in countries with low-level of innovation performance. In these countries' groups all quality indicators are significantly related to innovation performance. In countries with high innovation performance, high-level of internet skills and satisfaction of education measures are not related to innovation performance.

\section{Conclusions}

There are three main approaches for human capital measurement: the cost-based approach, the income-based approach and the education-based approach. At the macroeconomic level, human capital is usually measured by using education-based indicators. Hence, the indicators used in the present study are referenced from an education-based approach. After reviewing those indicators, the human capital measurement model consisting of three groups of indicators was formed. The indicators that 
were used in the model formation are as follows: participation in education indicators, education attainment indicators and quality indicators. What is more, the main three indicators were compiled by bringing together more specific elements. In other words, participation rate of young people aged 1524 in education as well as the percentage of adult population aged 25-64 in education and training are elements of participation in the education category. Tertiary educational attainment (age group 26-64) and population with upper secondary or tertiary education attainment are the elements of education attainment indicators group. The last group is quality indicators and it consists of the following elements: students' performance in mathematics, students' performance in reading, students' performance in science, high-level computer skills, high-level internet-skills and satisfaction of education.

After the human model was created, the correlation analysis was performed to assess the level of relationship between human capital factors and innovation performance. The correlation analysis was conducted within $26 \mathrm{EU}$ countries during 2002-2012. The analysis revealed that quality indicators are mostly related to innovation. This relation is even stronger in countries with low-level of innovative performance. The relationship between education attainment and innovation performance is ambiguous. In countries with low innovation performance, increasing level of education attainment is negatively related to innovation performance. In countries with high-level of innovation, tertiary education attainment is positively related to innovation performance

\section{References}

Acs, Z. J., Audretsch, D. B., \& Feldman, M. P. (1994) R\&D spillovers and recipient firm size, Review of Economics and Statistics, (100), 336-340.

Aghion, P., \& Durlauf, S. N. (2009). From Growth Theory to Policy Design, Commission on Growth and Development, Washington: IBRD/The World Bank, Working Paper, no. 57.

Ahmad, A.-A., Jawad, S. N., \& Bontis, N. (2010). Intellectual capital and business performance in the pharmaceutical sector of Jordan. Management decision, 48(1), 105-131.

Alexander, S. (2006). An Intellectual Capital Audit of the Grand Duchy of Luxembourg. World Bank, 19.

Bang, A. (2010). How to create business value in the knowledge economy. Accelerating thoughts of Peter F. Drucker. Management Decision, 48(4), 616-627.

Barro, R. J. (1996). Determinants of Economic Growth: A Cross-Country Empirical Study (Working Paper No. 5698). National Bureau of Economic Research.

Barro, R. J. (2001). Human Capital and Economic Growth. American Economic Review, (91), 12-17.

Barro, R. J., \& Lee, J.-W. (2011). A New Data Set of Educational Attainment in the World 1950-2010. Journal of Development Economics, 104, 184-198.

Barro, R. J., \& Sala-i-Martin, X. (2004). Economic growth (2nd ed). Cambridge, Massachusetts: MIT Press, 654.

Becker, G. S. (1975). Front matter, Human Capital: A Theoretical and Empirical Analysis, with Special Reference to Education. National Bureau of Economic Research, 22.

Benhabib, J., \& Spiegel, M. M. (1994). The role of human capital in economic development Evidence from aggregate cross-country data. Journal of Monetary Economics, 34, 143-173.

Benos, N., Karagiannis, S., \& Karkalakos, S. (2015). Proximity and growth spillovers in European regions: The role of geographical, economic and technological linkages. Journal of Macroeconomics, 43, 124-139.

Bowman, C., \& Ambrosini, V. (2010). How value is created, captured and destroyed. European Business Review. 22(5), 479-495.

Cabrilo, S., Uzelac, Z., \& Cosic, I. (2009). Researching indicators of organizational intellectual capital in Serbia. Journal of Intellectual Capital, 10(4), 573-587.

Chen S. (2003). Valuing intellectual capital using game theory. Journal of Intellectual Capital, 4(2), 191-201. 
Coe, D. T., Helpman, E., \& Hoffmaister, A. W. (2009). International R\&D spillovers and institutions. European Economic Review, 53(7), 723-741.

Curado, Henriques ir Bontis. (2011). Intellectual capital disclosure payback. Management Decision, 49(7), $1080-1098$

Dakhli, M., \& De Clercq, D. (2004). Human capital, social capital, and innovation: a multi-country study. Entrepreneurship \& Regional Development, 16(2), 107-128.

Díez, J. M., Ochoa, M. L., Prieto, M. B., \& Santidrian, A. (2010). Intellectual capital and value creation in Spanish firms. Journal of Intellectual Capital, 11(3), 348-367.

ESS Round 1: European Social Survey Round 1 Data (2002). Data file edition 6.4. Norwegian Social Science Data Services, Norway - Data Archive and distributor of ESS data for ESS ERIC. [Accessed 14.06.2014]. Available from http://www.europeansocialsurvey.org/data/download.html?r=1

ESS Round 2: European Social Survey Round 2 Data (2004). Data file edition 3.4. Norwegian Social Science Data Services, Norway - Data Archive and distributor of ESS data for ESS ERIC. [Accessed 14.06.2014]. Available from http://www.europeansocialsurvey.org/data/download.html?r=2

ESS Round 3: European Social Survey Round 3 Data (2006). Data file edition 3.5. Norwegian Social Science Data Services, Norway - Data Archive and distributor of ESS data for ESS ERIC. [Accessed 14.06.2014]. Available from http://www.europeansocialsurvey.org/data/download.html?r=3

ESS Round 4: European Social Survey Round 4 Data (2008). Data file edition 4.3. Norwegian Social Science Data Services, Norway - Data Archive and distributor of ESS data for ESS ERIC. [Accessed 14.06.2014]. Available from http://www.europeansocialsurvey.org/data/download.html?r=4

ESS Round 5: European Social Survey Round 5 Data (2010). Data file edition 3.2. Norwegian Social Science Data Services, Norway - Data Archive and distributor of ESS data for ESS ERIC. [Accessed 14.06.2014]. Available from http://www.europeansocialsurvey.org/data/download.html?r=5

ESS Round 6: European Social Survey Round 6 Data (2012). Data file edition 2.1. Norwegian Social Science Data Services, Norway - Data Archive and distributor of ESS data for ESS ERIC. [Accessed 14.06.2014]. Available from http://www.europeansocialsurvey.org/data/download.html?r=6

Eurostat (2015). Science and technology statistics. [Accessed 27.11.2015]. Available from http://www.europeansocialsurvey.org/data/conditions_of_use.html

Giménez, G., López-Pueyo, C., \& Sanaú, J. (2015). Human capital measurement in OECD countries and its relation to GDP growth and innovation. Medición del capital humano en los países ocde y su relacióncon el crecimiento del pib y la innovación, (39), 77-107.

Godoy, J. G. A. (2008). Capital intelectual y generación de valor. Monografías. [Accessed 18.12.2014]. Available from http://www.monografias.com/trabajos11/capint/capint.shtml

Green A. (2007). Intangible assets in plain business language. International Journal of Information and Knowledge Management Systems, 37(3), 238-248

Hanushek, E. A., \& Kimko, D. D. (2000). Schooling, Labor-Force Quality, and the Growth of Nations. American Economic Review, 90(5), 1184-1208.

Harris L. (2000). A theory of intellectual capital. Advances in Developing Human Resources, 2(1), 22-37

Hughes, C. (2010). "People as technology" conceptual model: toward a new value creation paradigm for strategic human resource development. Human resource development review, 9(1), 48-71.

INSEAD eLab. (2009). Who cares? Who dares? Providing the skills for an innovative and sustainable Europe. European Business Summit, 32 p.

Iturrioz, C., Aragon, C., \& Narvaiza, L. (2015). How to foster shared innovation within SMEs' networks: Social capital and the role of intermediaries. European Management Journal, 33(2), 104-115.

Jaffe, A. B. (1989). Real effects of academic research. American Economic Review, (79), 957-970. 
Jokūbauskienè, S. (2013). Informacijos ir komunikacijos specialistu strateginès lyderystès kompetenciju formavimas besimokančioje organizacijoje. Doctoral Dissertation. [Accessed 20.01.2016]. Available from http://vddb.library.lt/obj/LT-eLABa-0001:E.02 2013 D_20131230_081505-38536

Judson, R. (2002). Measuring human capital like physical capital: What does it tell us? Bulletin of Economic Research, 54(3), 209-231.

Karoglu, B. A., \& Eceral, T. O. (2015). Human Capital and Innovation Capacity of Firms in Defense and Aviation Industry in Ankara. Procedia - Social and Behavioral Sciences, (195), 1583-1592.

Keeble, D. (1997). Small firms, innovation and regional development in Britain in the 1990s. Regional Studies, (31), 281-293.

Krueger, A. B., \& Lindahl, M. (2001). Education for growth: why and for whom? Journal of Economic Literature, $X X X I X, 1101-1136$.

Le, T., Gibson, J., \& Oxley, L. (2005). Measures of human capital: A review of the literature (Treasury Working Paper Series No. 05/10). New Zealand Treasury. Retrieved from https://ideas.repec.org/p/nzt/nztwps/05-10.html

Lin, C. Y.-Y., \& Edvinsson, L. (2011). National intellectual capital a comparison of 40 countries. New York: Springer, $392 \mathrm{p}$.

Lucas, R. E. (1988). On the Mechanics of Economic Development. Journal of Monetary Economics, (22), 3-42.

Lyles, M. S. (2014). Organizational learning, knowledge creation, problem formulation and innovation in messy problems. European Management Journal, 32(1), 132-136.

Mačerinskienė, I., \& Viržintaitè, R. (2003). Human Capital Measurement Theory and Methods. Management of Organizations: Systematic Research, (28), 71-85.

Malgioglio, J. M., Carazay, C., Suardi, D., Bertolino, G., \& Diaz, T. (2001). Capital intelectual: el intangible generador de valor en las empresas del tercer milenio. Sextas Jornadas "Investigaciones en la Facultad" de Sciencias Ecónomicas y Estadística. Noviembre de, 350-360.

Malhotra, Y. (2003). Measuring Knowledge Assets of a Nation: Knowledge Systems for Development. United Nations Advisory Meeting of the Department of Economic and Social Affairs Division for Public Administration and Development Management, $52 \quad p \quad$ Retrieved from http://km.brint.com/KnowledgeManagementMeasurementResearch.pdf.

Malmelin, N. (2007). Communication capital. Modelling corporate communications as an organisational asset. Corporate Communications: An International Journal, 12(3), 298 - 310.

McLean, G. N. (2006). Organization development: priciples, processes, performance. San Francisco: BerrettKoehler.

Meschi, E., \& Scervini, F. (2014). Expansion of schooling and educational inequality in Europe: the educational Kuznets curve revisited. Oxford Economic Papers, 66(3), 660-680.

Morrisson, C., \& Murtin, F. (2013). The Kuznets curve of human capital inequality: 1870-2010. Journal of Economic Inequality, 11(3), 283-301.

Nelson, R. R., \& Phelps, E. S. (1966). Investment in Humans, Technological Diffusion, and Economic Growth. The American Economic Review, 56(1/2), 69-75.

OECD. (1998). Human Capital Investment An international Comparison: An international Comparison. OECD Publishing, 116p. [Accessed 20.06.2014]. Available from http://www.oecd-ilibrary.org/education/human-capitalinvestment_9789264162891-en

OECD. (2010). Social Capital, Human Capital and Health. What is the Evidence? [Accessed 27.06.2014]. Available from http://www.oecd.org/innovation/research/45760738.pdf

Papalia, R. B., Bertarelli, S., \& Filippucci, C. (2011). Human capital, technological spillovers and development across OECD countries. In AlmaLaurea Working Papers (Vol. 15, p. 19). Bologna: AlmaLaurea Working Papers. Retrieved from http://core.ac.uk/download/pdf/6330757.pdf 
Pasher, E., \& Shachar, S. (2007). The Intellectual Capital of the State of Israel. Office of the Chief Scientist Jerusalem. [Accessed 21.01.2016]. Available from http://www.moital.gov.il/NR/rdonlyres/94A44BDD-F78D410E-9E28-F17C1E0BE6BD/0/intellectualcapitalnew.pdf

Pinto, H., Cruz, A. R., \& Combe, C. (2015). Cooperation and the emergence of maritime clusters in the Atlantic: Analysis and implications of innovation and human capital for blue growth. Marine Policy, 57, 167-177.

Pitelis, C. N. (2009). The co-evolution of organizational value capture, value creation and sustainable advantage. Organization Studies, (30), 1115 - 1139.

Potelienè, S., \& Tamašauskienè, Z. (2014). Žmogiškojo kapitalo konceptualizacija: raida, samprata ir formavimas. Business Systems \& Economics, 4(1), 89-106. http://doi.org/10.13165/VSE-14-4-1-08

Rebelo, S. (1991). Long-Run Pollicy Analysis and Long-Run Growth. Journal of Political Economy, (99), 50021.

Ritsila, J. J. (1999). Regional differences in environments for enterprises. Entrepreneurship \& Regional Development, (11), 187-202.

Romer, P. (1990). Endogenous Technological Change. Journal of Political Economy, 98(5), S71-102.

Schuller, T. (2001). The complementary roles of human and social capital. Canadian Journal of Policy Research, 2(1), 18-24.

Snyder, H., Witell, L., Gustafsson, A., Fombelle, P., \& Kristensson, P. (2016). Identifying categories of service innovation: A review and synthesis of the literature. Journal of Business Research, Vol. 69(7), 2401-2408.

Stepanovas, A., \& Ostašenkovaitė, K. (2013). Inovatyvių projektų vertinimo problema. Verslas XXI amžiuje, $5(1), 7-12$

Stewart, T. A. (1997). Intellectual capital: the new wealth of organisations. Doubleday Dell Publishing Group: New York.

Swart J. (2006). Intellectual capital: disentangling an enigmatic concept. Journal of Intellectual Capital, 7(2), $136-159$.

Tomer, J. F. (2003). Personal Capital and Emotional Intelligence: An Increasingly Important Intangible Source of Economic Growth. Eastern Economic Journal, 29(3), 453-470.

Užienè, L. (2015). Open Innovation, Knowledge Flows and Intellectual Capital. Procedia - Social and Behavioral Sciences, 213, 1057-1062.

Valentinavičius, S. (2006). Inovacinio verslo plètra: problemos ir galimybès. Ekonomika, 108-128.

Vandenbussche, J., Aghion, P., \& Meghir, C. (2006). Growth, Distance to Frontier and Composition of Human Capital, Journal of Economic Growth, 11(2), 97-127.

Vick, T. E., Nagano, M. S., \& Popadiuk, S. (2015). Information culture and its influences in knowledge creation: Evidence from university teams engaged in collaborative innovation projects. International Journal of Information Management, 35(3), 292-298.

Wang, G. G., \& Swanson, R. A. (2008). Economics and human resource development: A rejoinder. Human Resource Development Review, (7), 358 - 362.

Wang, J. (2016). Knowledge creation in collaboration networks: Effects of tie configuration. Research Policy, (45), 68-80.

Welsum, D., \& Lanvin, B. (2012). e-Leadership Skills (Vision Report). INSEAD, Prepared for the European Commission. Available http://eucases.eu/fileadmin/TYPO3TUT/files/Vision\%20report.pdf

Zapata, J. E. V. (2001). Nuevos conceptos del capital intelectual. Revista CES Medicina, 15(1), 81-90. 